\title{
PENGEMBANGAN E-MODULE PEMBELAJARAN MATEMATIKA PADA SISWA KELAS V SD NEGERI 14 KOTO BARU
}

\author{
Restina $^{1}$, Dwi Novri Asmara ${ }^{2}$, Rauldatul Husni ${ }^{3}$ \\ ${ }^{1}$ Mahasiswa Universitas Dharmas Indonesia ${ }^{2}$ Dosen Universitas Dharmas Indonesia \\ ${ }^{3}$ Dosen Universitas Dharmas Indonesia \\ email:resti99phone@gmail.com
}

Received: May 25, $2021 \quad$ Revised: May 28, $2021 \quad$ Accepted: June 4, 2021

\begin{abstract}
ABSTRAK
E-Module adalah modul elektronik yang dapat menambahkan gambar, audio, video. Penelitian ini bertujuan untuk mengembangkan e-module pembelajaran matematika kelas $\mathrm{V}$ yang valid, praktis, dan efektif. Penelitian ini dilatar belakangi oleh lemahnya pemahaman siswa kelas $\mathrm{V}$ pada pembelajaran matematika, disebabkan jam di sekolah dibatasi terbilang waktu yang singkat dan siswa yang lambat berpikir ketinggalan pembelajaran. Siswa beranggapan matematika sulit, hal ini membuat hasil belajar siswa rendah. Untuk mengatasi hal tersebut adalah dengan menggunakan penunjang pembelajaran khususnya e-module pembelajaran matematika, siswa belajar di rumah dengan pantauan orang tua. Metode yang digunakan dalam penelitian ini adalah 4- $D$, dengan menggunakan model pengembangan 4-D yang terdiri dari tahap pendefinisian (define), perancangan (design), pengembangan (development), dan penyebaran (desseminate). Tahap pendefinisian meliputi analisis kebutuhan, analisis Karakteristik siswa, dan analisis materi. Tahap perancangan dilakukan perancangan terhadap perangkat pembelajaran yaitu rancangan instrument, rancangan kerangka, rancangan awal, tahap pengembangan dilakukan uji validitas, uji praktikalitas, dan uji efektivitas, dan tahap penyebaran ini dilakukan di SD N 14 Koto Baru. Hasil penilaian $e-$ module pembelajaran matematika pada uji validitas oleh tiga orang ahli mempunyai skor rata-rata $84 \%$, Termasuk dalam kategori sangat valid, uji praktikalitas dengan skor rata-rata 92\% dikategorikan sangat praktis, sedangkan hasil efektifitas e-module pembelajaran matematika dengan skor rata-rata $83 \%$ dikategorikan sangat efektif. Berdasarkan hasil analisis di atas, dapat disimpulkan bahwa e-module pembelajaran matematika kelas V SD sangat sesuai dengan ketentuan di Sd N 14 Koto Baru. Penelitian ini menghasilkan e-module pembelajaran matematika kelas $\mathrm{V}$ dengan kriteria sangat valid, sangat praktis dan sangat efektif.
\end{abstract}

Kata Kunci: Pengembangan, E-module, matematika, Model 4D. 


\section{PENDAHULUAN}

Pendidikan adalah salah satu fondasi awal bagi jenjang pendidikan untuk proses pemanusiaan dalam masyarakat yang berbudaya. Pendidikan adalah sebuah keharusan bagi manusia untuk meningkatkan ilmu pengetahuan. Pasal 1 ayat (1) Undang-Undang Nomor 20 Tahun 2003 tentang Sistem Pendidikan Nasional menyatakan bahwa "Pendidikan adalah usaha sadar dan terencana untuk mewujudkan suasana belajar dan proses pembelajaran agar peserta didik secara aktif mengembangkan potensi dirinya untuk memiliki kekuatan spiritual keagamaan, pengendalian diri, kepribadian, kecerdasan, akhlak mulia serta keterampilan yang diperlukan dirinya, masyarakat, bangsa dan negara”.

Pendidikan merupakan usaha mendewasakan manusia secara sadar dan sengaja melalui upaya pengajaran, tanpa adanya pendidikan manusia tidak akan mampu menghadapi perubahan yang terjadi akibat kemajuan teknologi. JPeserta didik merupakan anggota masyarakat yang berusaha mengembangkan potensi diri melalui jenjang, jalur dan jenis pendidikan tertentu untuk terus mengikuti kemajuan teknologi yang tidak dapat dihindari.

Dilihat dari hasil ujian harian (UH) siswa yang di bawah KKM perhatikan gambar berikut:

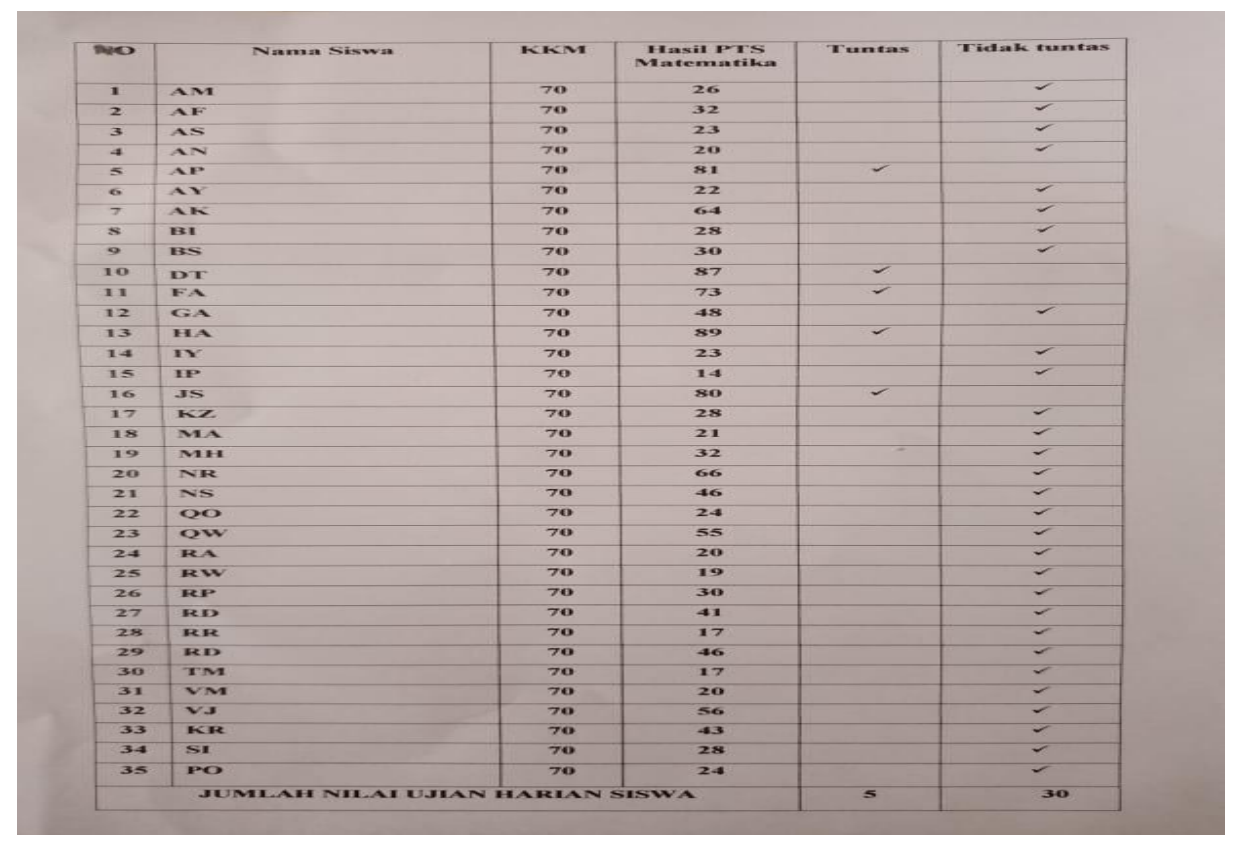

Gambar 1. Buku Penilaian UH Guru

Melihat gambar nilai UH matematika pada siswa kelas 5 yang tuntas 14\% yang tidak tuntas $86 \%$. Dari pengamatan awal saya pada 04 Agustus 2020 proses pembelajaran terlaksana secara daring menggunakan aplikasi whatsApp di handphone masing-masing siswa untuk membagikan semua informasi atau proses belajar mengajar. Pada 17 September 
2020 proses pembelajaran mulai aktif di sekolah tetapi jam pembelajarannya di batasi membuat waktu belajar di sekolah terbilang singkat, dalam proses belajar mengajar di kelas guru menggunakan modul cetak dalam proses belajar materi pada siswa, siswa yang lambat berpikir ketinggalan pembelajaran karena adanya pembatasan waktu belajar, siswa kurang semangat dalam proses pembelajaran matematika dan siswa lebih sering bermain bermalasan di kelas. Pada 05 maret 2021 wawancara yang di lakukan kepada salah satu siswa yaitu beranggapan pembelajaran matematika sulit di pahami dan rumit karena selalu berhubungan dengan angka, rumus, dan hitung-menghitung. Wawancara dengan guru yaitu keterbatasan waktu yang membatasi proses pembelajaran membuat materi yang di ajarkan di sederhanakan, kurangnya media yang menarik motivasi belajar siswa, sebelum belajar siswa sudah merasa takut atau kurang percaya diri dalam menerima materi matematika. Jadi media yang di gunakan dalam proses pembelajaran itu sangat berpengaruh dalam proses belajar mengajar.

Media yang digunakan yaitu e-module dari modifikasi modul konvensional dengan memadukan pemanfaatan teknologi informasi, sehingga modul yang ada di sekolah dapat lebih menarik minat belajar siswa, e-module sebagai bahan penunjang pembelajaran dapat membantu siswa belajar di rumah secara mandiri. Semenjak Corona Virus Disease (covid-19) pemerintah menerapkan kebijakan social distancing atau pembatasan social, jadi sistem pembelajaran dari rumah masing-masing yaitu daring, SD N 14 Koto Baru melaksanakan proses belajar mengajar dengan menggunakan sumber youtube yang di share di group WhatsApp kelas V, untuk menghindari siswa melihat konten-konten yang tidak sepatutnya dicontoh oleh siswa kelas V SD e-module memiliki manfaat yaitu dapat mengalihkan perhatian siswa dari membuka konten yang kurang bermanfaat, memberikan pilihan kepada siswa untuk menggali sumber belajar yang menarik, dan menjawab rasa ingin tahu siswa, memberi solusi kepada siswa untuk dapat memanfaatkan teknologi informasi dan komunikasi secara bijak, memberikan pilihan kepada guru untuk menjawab tantangan kemajuan teknologi dan informasi suka maupun tidak suka akan berdampak pada dunia pendidikan dan pembelajaran.

Di Sekolah Dasar, guru merupakan factor yang penting dalam menentukan keberhasilan suatu pembelajaran salah satunya pembelajaran matematika sesuai dengan tuntutan kurikulum. Menurut Kenedi (2018) pembelajaran matematika merupakan pembelajaran yang diajarkan dari tingkat dasar sampai tingkat perguruan tinggi, pengembangan memiliki dua visi untuk mencapai tuntutan masa sekarang dan masa depan. Visi matematika yang pertama adalah mengarahkan pembelajaran matematika untuk 
memahami konsep dan ide dalam pembelajaran matematika yang digunakan untuk menyelesaikan masalah matematika dan ilmu pengetahuan lainya, sedangkan visi kedua lebih mengarahkan kepada tuntutan masa depan yaitu memberikan kesempatanya untuk menumbuh kembangkan kemampuan menalar yang logis, sistematis, kritis, kreatif, cermat, rasa keindahan, percaya diri, mengembangkan sifat obyektif yang sangat dibutuhkan untuk menghadapi masa depan. Meurut Prananda (2021) Keberhasilan pembelajaran di kelas tidak hanya berpusat pada siswa, tetapi dengan pemilihan strategi atau media pembelajaran yang sesuai dengan bahan pembelajaran, faktor guru juga dapat menentukan keberhasilan pembelajaran di kelas. Pembelajaran adalah proses interaksi antara guru dan siswa, peristiwa pembelajaran terjadi ketika siswa secara aktif dengan lingkungan belajar yang dirancang oleh guru.

Dalam pandangan kurikulum 2013 kegiatan pembelajaran merupakan proses pendidikan yang memberikan kesempatan bagi siswa agar dapat mengembangkan segala potensi yang mereka miliki menjadi kemampuanyang semakin lama semakin meningkat dapat dilihat dari aspek sikap, pengetahuan, dan keterampilan. Menurut Ramadhani \& Fitri (2020) bahwa "Tuntutan dari Abad 21 kurikulum 2013 dan revolusi industri saling beririsan satu sama lain”. Sekarang dunia memasuki era revolusi industri generasi 4.0 telah ditandai dengan peningkatan konektivitas, interaksi serta perkembangan sistem digital, kecerdesan artifisial, dan visual. Dengan semakin kedepan batas antara manusia, mesin dan sumber daya lainnya, teknologi informasi dan komunikasi tentu berimbas pada berbagai sektor kehidupan. Salah satu yang berdampak dalam sektor kehidupan adalah sistem pendidikan di Indonesia. Pendidikan 4.0 merupakan respons terhadap kebutuhan revolusi industri 4.0 yang mana manusia dan teknologi diselaraskan untuk menciptakan peluang-peluang baru dengan kreatif dan inovatif. Kemajuan teknologi informasi salah satunya adalah handphone sekarang hampir seluruh masyarakat tidak lepas dari handphone, dunia pedidikan memanfaatkan sebagai sarana pembelajaran kemajuan, karena jam sekolah di kurangi siswa yang lamban akan ketinggalan pembelajaran tetapi hal ini bisa di atasi dengan menggunakan media pembelajaran E-Module yang dapat menampilkan teks, gambar, animasi, dan vidio melalui perangkat elektronik siswa dan siswa dapat terbantu dalam ketinggalan pembelajaran matematika. Tujuan menggunakan e-module kepada siswa kelas $\mathrm{V}$ yaitu dapat membantu siswa memahami materi pembelajaran, menjadikan siswa mampu belajar secara mandiri, menumbuhkan minat belajar siswa, semangat dalam melaksanakan proses belajar di sekolah maupun di rumah. 
E-module merupakan sebuah bentuk bahan ajar secara mandiri dengan alat sarana pembelajaran yang berisi materi, metode, batasan-batasan, dan cara mengevaluasi yang dirancang secara sistematis dan menarik untuk mencapai kompetensi yang diharapkan sesuai dengan tingkat kompleksitasnya secara elektronik. Hal ini sejalan menurut Suarsana \& Mahayukti (2013) Kemajuan zaman membuat proses pembelajaran yang bersifat konvensional secara bertahap mengalami perubahan menjadi pembelajaran berbasis computer. Penggunaan multimedia pembelajaran erat kaitannya dengan istilah CAI (Computer Assist Instruction) dan CMI (Computer Managed Instruction). CAI dapat diartikan sebagai tutor yang menggantikan guru di dalam kelas, dalam hal ini digantikan oleh computer, kelebihannya dibandingkan dengan modul cetak adalah sifatnya yang multimedia memudahkan dalam navigasi, memungkinkan menampilkan gambar, audio, video dan animasi. Menurut Ricu Sidiq \& Najuah (2020) E-module adalah modul yang produk yang dianggap cukup ideal sekarang ini. Karena mendukung penggunaan multiproduk (keterpaduan audio-visual berbentuk video), interaktifitas yang tinggi, dan pembelajaran multi sumber (dengan koneksi jaringan internet) sehingga dapat melengkapi kekurangankekurangan yang ada pada buku teks.

Materi matematika yang disampaikan dalam e-module yaitu KD matematika 3.5 Menjelaskan dan menentukan volume bangun ruang dengan menggunakan satuan volume (seperti kubus satuan) serta hubungan pangkat tiga dengan akar pangkat tiga, KD 3.6 Menjelaskan dan menentukan jaring-jaring bangun ruang sederhana (kubus dan balok), KD 3.7 Menjelaskan data dengan diri peserta didik atau lingkungan sekitar serta cara pengumpulannya, dan KD 3.8 Menjelaskan penyajian data yang berkaitan dengan diri peserta didik dan membandingkan dengan data dari lingkungan sekitar dalam bentuk daftar, tabel, diagram gambar (piktogram), diagram batang, atau diagram garis.

\section{METODE}

\section{Jenis Penelitian}

Dalam penelitian ini menggunakan jenis penelitian dan pengembangan atau Research and Development (R\&D). Penelitian dan pengembangan merupakan proses atau langkahlangkah untuk mengembangkan suatu produk baru atau menyempurnakan produk yang sudah

ada, yang dapat di pertanggung jawabkan. Penulis mengembangkan sebuah produk baru yang belum di gunakan di SD 14 Koto Baru, Langkah-langkah mengembangkan E-Module pembelajaran matematika ini mengikuti model pengembangan $4 D$ menggunakan empat 
tahapan yaitu tahap pendefinisian (define), tahap perancangan (design), tahap pengembangan (develop), dan tahap (Disseminate) penyebaran, Thiagarajan (Kurniawan \& Dewi, 2017).

Dalam penelitian ini data kualitatif dan data kuantitatif yaitu 1) Analisis data kualitaif seluruh penilaian, saran, dan masukan dari validator selanjutnya dianalisis secara kualitatif. Hasil berupa saran dan masukan yang telah diperoleh dari ahli/pakar dijelaskan dalam bentuk deskriptif. Data ini digunakan untuk memperbaiki produk yang dihasilkan. 2) Analisis data kuantitatif yang diperoleh dari angket tertutup dianalisi dengan perhitungan skor yang diperoleh dari skala Likert. Uji ini dilakukan untuk mengetahui nilai kevalidan yang digunakan dan untuk mendapatkan ukuran kesesuain dari produk yang dikembangkan (Budiaji, 2013).

\section{Teknik Pengumpulan dan Analisis Data}

Teknik pengumpulan data dalam penelitian pengembangan e-module ini menggunakan tiga jenis, yaitu: a) Teknik observasi lapangan dilakukan dengan mengamati proses pembelajaran di kelas. Tujuannya untuk memperoleh deskripsi kegiatan guru dalam menerapkan pendekatan (metode/teknik) dalam pembelajaran, bahan ajar, media, evaluasi dan perilaku siswa dalam mengikuti pembelajaran. b) Teknik wawancara dilakukan untuk mengumpulkan data dan mendapatkan informasi yang berhubungan dengan fakta yang diperlukan oleh peneliti untuk memenuhi tujuan penelitian. c) Kuesioner merupakan teknik pengumpulan data yang dilakukan dengan cara memberi seperangkat pertanyaan atau pernyataan tertulis kepada responden untuk dijawabnya (Sugiyono, 2016).

Teknik analisis data yang digunakan adalah teknik analisis deskriptif. Langkah analisis tersebut akan dijabarkan sebagai berikut. 1) Analisis Validasi data yang berasal dari lembar validasi dianalisis menggunakan kuantitatif. Hasil validasi akan disajikan dalam bentuk tabel. Analisis dilakukan dengan menggunakan skala Likert. Langkah-langkah yang dilakukan untuk menetukan validitas media berdasarkan atas data yang diperoleh dari lembar validasi. 2) Analisis Praktikalitas data praktisan dikumpulkan melalui pengisian angket, instrumen yang digunakan adalah angket respon guru disusun dalam bentuk skala likert. 3) Analisis Efektifitas Keefektifan E-Module dapat diketahui dengan menganalisis data tes hasil belajar siswa. Untuk masing-masing analisis dalam skala 0-100, diharapkan siswa bisa mencapai ketuntasan minimal (KKM) yang sudah ditetapkan 70. Jika nilai siswa lebih dari 60\% maka bisa dikatakan efektif (Sugiyono, 2011). 


\section{PEMBAHASAN}

Berdasarkan penelitian mengenai pengembangan e-module pembelajaran matematika kelas V SD yang telah dikembangkan, maka diperoleh hasil penelitian dan penjelasan pada tahap Define, Design, Develop, Disseminate (4D). Proses pengembangan dimulai dari uji validitas sampai pada proses uji efektifitas. Setelah pengumpulan data, maka hasil dari pengumpulan data tersebut di deskripsikan sebagai berikut: 1) Define (Pendefinisian) tahap define ini mencakup tiga langkah pokok, yaitu analisis kebutuhan, analisis siswa (leaner analysis), dan analisis materi (material analysis). 2) Design (Perancangan) Rancangan awal adalah rancangan E-module pembelajaran yang harus dilakukan sebelum uji coba dilapangan dalam penelitian. Dalam penyusunan rancangan awal ini akan menghasilkan sebuah rancangan berupa draft e-module pertama pada gambar berikut: Produk yang dikembangkan oleh peneliti memiliki komponen-komponen yang bertujuan untuk memudahkan peserta didik memahami materi dalam proses pembelajaran.

Tabel 1. Hasil Rancangan E-Module

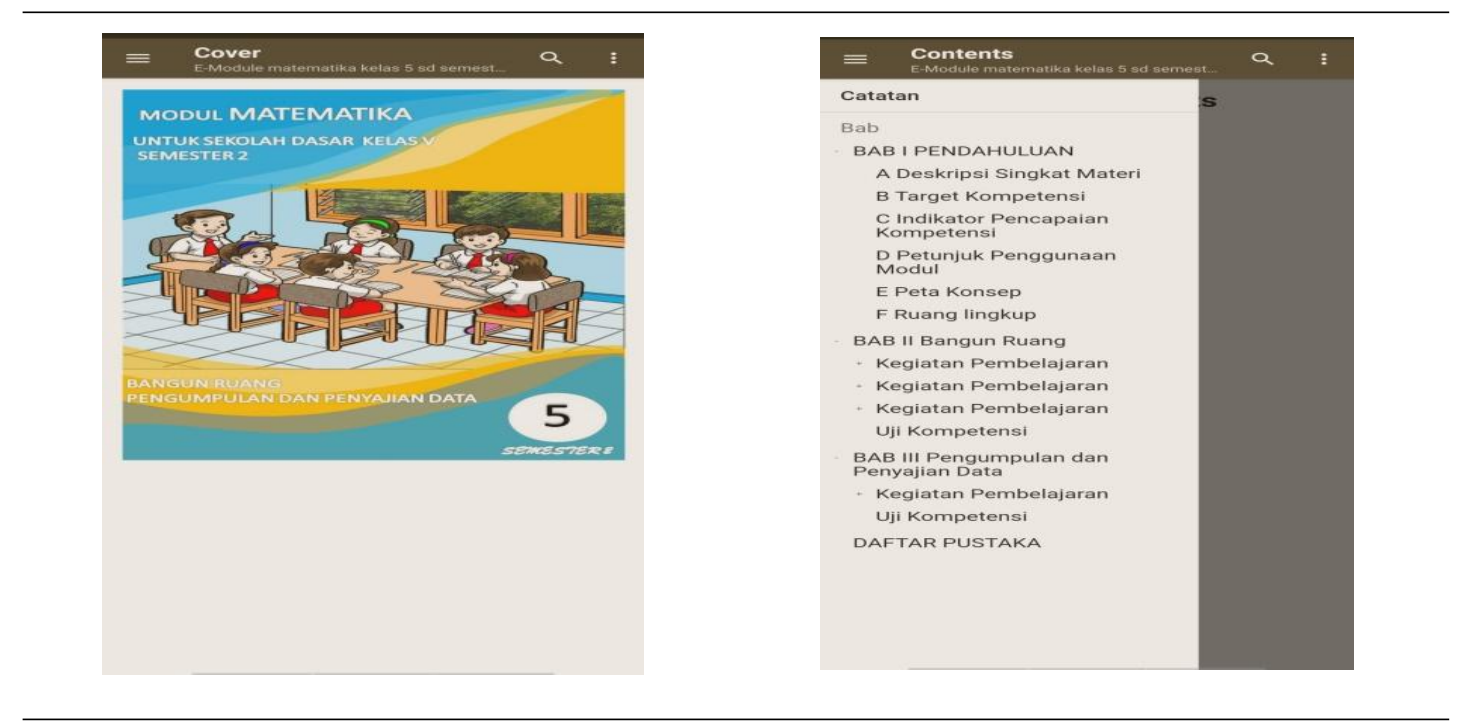


F-MODULE MATEMATLKA KELAS V SD

BAB I PENDAHULUAN
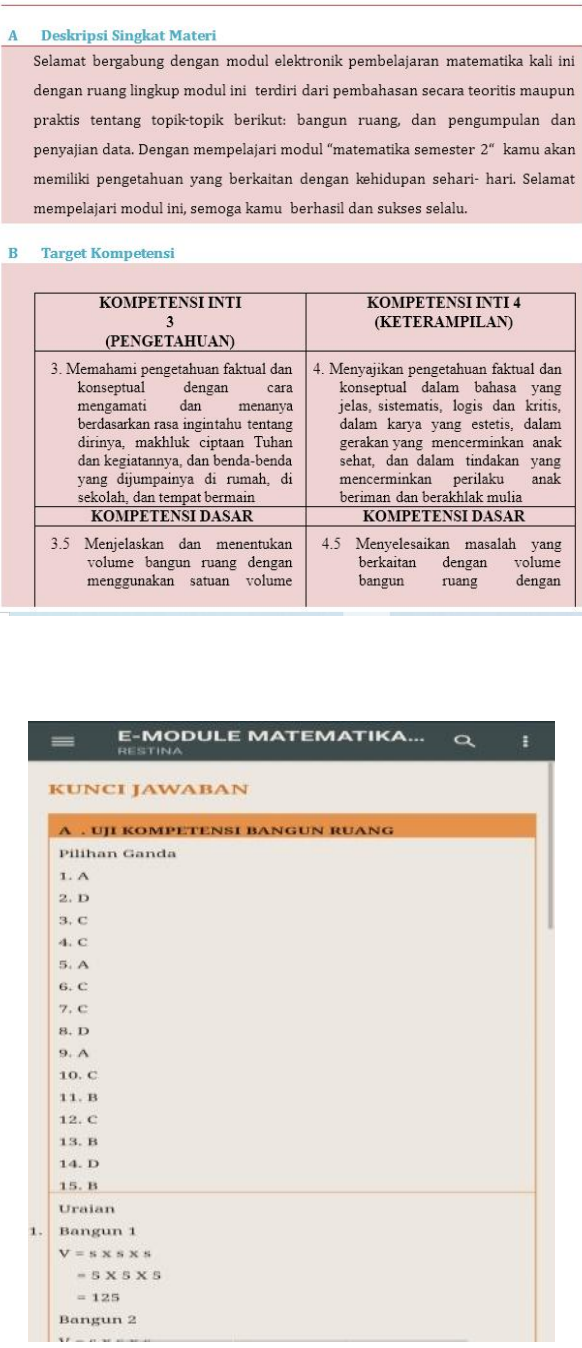
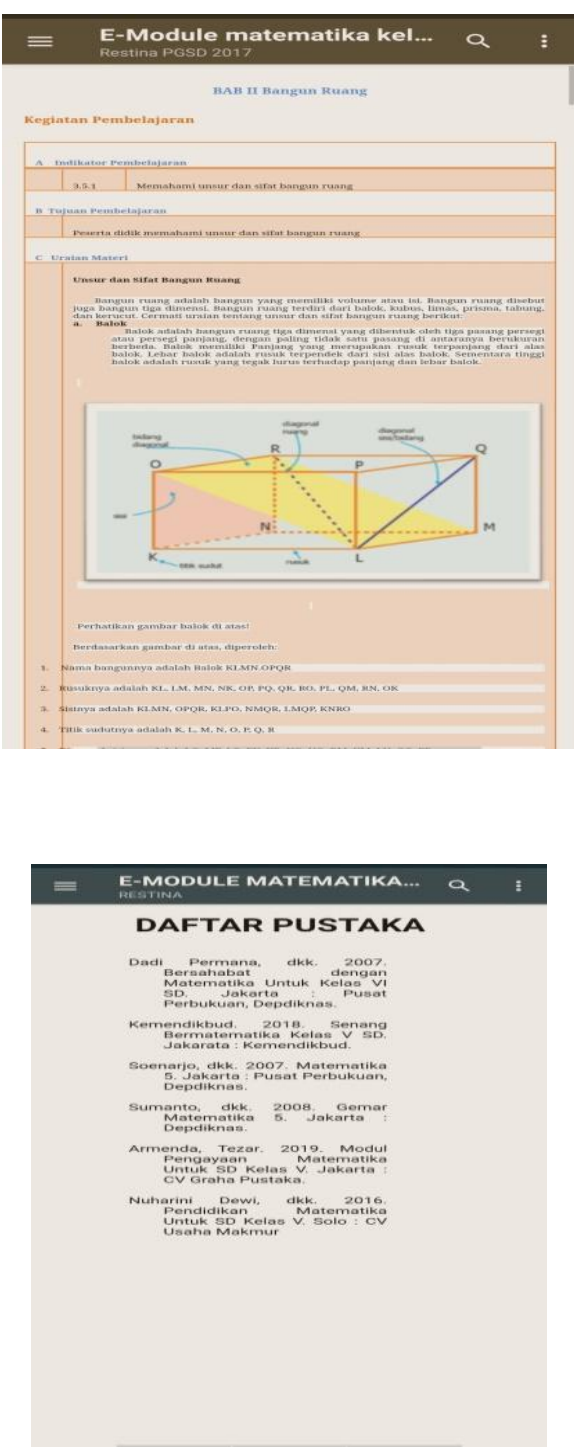

1. Hasil Tahap Pengembangan (Deveploment)

Tabel 2. Data Validasi E-Module Pembelajaran Matematika

\begin{tabular}{lllcc}
\hline NO & \multicolumn{1}{c}{ Validator } & Hasil $\mathrm{v}=\frac{f}{n} \times 100 \%$ & Kategori & Keterangan \\
\hline \multirow{2}{*}{$\begin{array}{l}\text { Eka Filahanasari, } \\
\text { M.Pd }\end{array}$} & $\mathrm{v}=79 / 105 \times 100 \%$ & Valid & FKIP \\
& $\mathrm{v}=75 \%$ & & UNDHARI \\
& $\begin{array}{l}\text { Dr. Raimon Efendi, } \\
\text { M.Kom }\end{array}$ & $\mathrm{v}=101 / 105 \times 100 \%$ & Sangat & Dosen \\
& $\mathrm{v}=96 \%$ & Valid & FILKOM \\
& & & UNDHARI
\end{tabular}




\begin{tabular}{llrc}
\hline Aprimadedi, M.Pd & $\mathrm{v}=85 / 105 \times 100 \%$ & Sangat & $\begin{array}{c}\text { Dosen } \\
\text { Rata-Rata }\end{array}$ \\
& $\mathrm{v}=81 \%$ & Valid & FKIP \\
& $\mathrm{v}=252 / 3$ & SNDHARI \\
& $\mathrm{v}=84 \%$ & Valid & \\
\hline
\end{tabular}

Tabel 3. Data Praktikalitas E-Module Pembelajaran Matematika

\begin{tabular}{lllll}
\hline No & Nama Guru & Hasil $\mathrm{p}=\frac{f}{n} \times 100 \%$ & Kategori & \multicolumn{2}{c}{ Keterangan } \\
\hline 1. & Zailani Sidik, & $\mathrm{p}=23 / 25 \times 100 \%$ & Sangat Praktis & Wali Kelas V \\
& S.Pd & $\mathrm{p}=92 \%$ & SD N 14 Koto \\
& & & Baru & \\
\hline
\end{tabular}

Tabel 4. Data Uji Coba E-Module Pembelajaran Matematika

\begin{tabular}{lllll}
\hline No & \multicolumn{1}{c}{ Kriteria } & & Jumlah & Persen \\
\hline 1. & Tuntas & $\mathbf{2 9}$ & $\mathbf{8 3 \%}$ \\
2. & Tidak Tuntas & $\mathbf{6}$ & $\mathbf{1 7 \%}$ \\
\hline
\end{tabular}

Setelah melakukan analisis validasi ahli, praktis, dan efektifitas. Maka terdapatlah analisis akhir sebagai berikut: a) Validasi ahli Berdasarkan hasil penilaian validasi e-module yang telah dirancang peneliti mendapat rata-rata $84 \%$ dikategorikan sangat valid. Jadi hasil akhirnya e-module pembelajaran matematika bisa diterapkan di Sekolah Dasar. b) Uji coba praktis Berdasarkan hasil penilaian angket praktisi guru kelas $\mathrm{V}$ e-module pembelajaran matematika yang telah dirancang peneliti mendapat rata-rata 92\% dikategorikan sangat praktis. Jadi hasil akhirnya e-module pembelajaran matematika bisa membantu guru dalam proses belajar dan e-module bisa diterapkan di Sekolah Dasar. c) Uji coba efektif Berdasarkan uji coba soal kepada siswa peneliti mendapatkan hasil penilaian, Ketuntasan hasil belajar siswa dengan rata-rata $83 \%$ dikategorikan sangat efektif. Sedangkan ketidak tuntasan hasil belajar siswa dengan rata-rata 17\% di kategorikan tidak efektif. Jadi hasil akhirnya e-module pembelajaran matematika sangat efektif untuk membantu proses belajar siswa di sekolah maupun di rumah. 


\section{Desseminate (penyebaran)}

Tahap disseminate merupakan tahap penyebarluasan dan merupakan tahap akhir dari tahap penelitian dan pengembangan ini. Pada tahap ini penyebaran di lakukan di SD N 14 Koto Baru dengan cara mengirim file pembelajaran melalui group WhatsApp kelas V dan siswa mendownload file tersebut dengan membuka aplikasi Reasily yang telah terpasang di hanphone setiap siswa.

Pengembangan e-module pembelajaran matematika pada siswa kelas V SD Negeri 14 Koto Baru merupakan media penunjang siswa dan guru dalam proses belajar mengajar, $e$ module dikembangkan harus memperhatikan keragaman karakter siswa, lingkungan sekolah. Dalam proses pengembangan peneliti menggunakan model $4-D$ yang terdiri dari 4 tahap yaitu: define, design, develop, dessiminate. Tahap pendefinisian bertujuan untuk memperoleh data yang diperlukan oleh peneliti, yaitu melaksanakan analisis kebutuhan, analisis siswa, analisis materi. Dari tahap ini peneliti memperoleh data awal yang di butuhkan oleh sekolah dasar yaitu e-module pembelajaran yang dapat menunjang proses belajar, analisis materi dilaksanakan untuk mengetahui kompetensi dasar yang harus dicapai oleh siswa.

Hasil uji validitas menunjukkan bahwa produk yang dikembangkan berada pada karakteristik sangat valid, sehingga e-module layak digunakan untuk siswa kelas tinggi. Produk yang dihasilkan berada pada kategori sangat valid karena memiliki karakteristik, yaitu: 1) Tujuan pembelajaran sesuai dengan indikator dan dinyatakan dengan jelas, 2) Teknik penilaian dan tampilan sesuai dengan karakteristik siswa, 3) Materi pembelajaran sesuai dengan kurikulum yang berlaku, 4) Desain e-module menggunakan gambar, video, dan warna yang menarik, 5) Bahasa yang digunakan dapat meningkatkan minat belajar siswa, 6) E-module dapat membantu proses belajar siswa yang lambat dan ketinggalan pembelajaran, 7) Cakupan teori yang dipaparkan dengan jela dan logis, 8) grafik digunakan dengan jelas. Menurut (Sugiyono, 2016), menyatakan bahwa "suatu instrument dikatakan valid bila instrument tersebut dapat digunakan untuk mengukur apa yang seharusnya diukur". Uji validitas yang dilakukan meliputi: validitas isi, validitas konstruk, dan validitas bahasa. Berdasarkan isinya perangkat dinyatakan sangat valid oleh validator karena perangkat pembelajaran yang dikembangkan telah sesuai dengan materi yang seharusnya disajikan.. Menurut (Matondang, 2009) Validitas adalah sejauh mana ketepatan dan kecermatan suatu instrument pengukur (tes) dalam melakukan fungsi 
ukurnya. Uji validitas ini digunakan untuk menunjukkan sejauh mana media yang kita kembangkan sesuai dengan kegunaan dan kebutuhan.

Hasil dasi validasi e-module pembelajaran matematika kelas $\mathrm{V}$ ini di isi oleh tiga validator yaitu dosen FKIP dan FILKOM UNDHARI. Validator adalah yang menvalidasi e-module pembelajaran matematika yang terdiri dari tiga aspek yang dinilai, diantaranya adalah aspek isi atau materi, aspek konstruksi atau komponen penyajian serta aspek bahasa, dari tiga sapek tersebut mencakup 21 pertanyaan. Berdasarkan hasil dari ke 3 validator e-module pembelajaran matematika didapatkan dengan jumlah presen $84 \%$ yaitu dikategorikan sangat valid.

Maka dapat disimpulkan bahwa e-module pembelajaran matematika sesuai kegunaan dan kebutuhan untuk siswa kelas V SD Negeri 14 Koto Baru. Walaupun demikian e-module pembelajaran matematika ini tetap dilakukannya revisi, dikarenakan hasil akhir dari ke tiga validator dua memberi keputusan bahwa e-module pembelajaran matematika sangat valid dengan sedikit revisi dan satu validator valid tanpa revisi. Setelah melakukan perbaikan maka e-module pembelajaran matematika dikategorikan sangat valid.

Hasil dari praktikalitas e-module pembelajaran matematika kelas $\mathrm{V}$ ini didapatkan dari hasil analisis penilaian angket respon guru. Guru diminta mengisi angket praktikalitas e-module pembelajaran matematika berdasarkan petunjuk pengisian. Berdasarkan hasil dari penilaian praktisi oleh guru kelas V SD Negeri 14 Koto Baru bapak Zailani Sidik, S.Pd, mendapatkan persen nilai 92\% maka e-module pembelajaran matematika dikategorikan sangat praktis. Praktis dalam KBBI didefenisikan dengan berdasarkan, mudah, dan senang memakainya dan praktisan di artikan perihal dapat disimpulkan bahwa praktikalitas dikatakan praktis jika terdapat kesesuaian antara harapan dan penilaian. Praktikalitas berkaitan dengan kemudahan dan kemajuan yang di dapatkan siswa dengan menggunakan bahan ajar, maupun produk lainnya.

Dari analisis di atas maka dapat disimpulkan bahwa e-module pembelajaran matematika praktikalitas dilakukan dengan 1 guru di sekolah mendapatkan nilai $92 \%$ maka e-module pembelajaran kelas $\mathrm{V}$ dapat memudahkan siswa dalam proses pembelajaran sesuai dengan harapan dan penilaian dari angket respon guru kelas.

Hasil dari efektifitas e-module pembelajaran matematika dapat dilihat dari hasil belajar kelas V SD Negeri 14 Koto Baru, dengan jumlah 35 orang siswa. Apakah nilai yang diperoleh siswa telah mencapai KKM yang ditentukan. Berdasarkan penelitian yang 
telah dilakukan, didapatkan persen nilai 83\% yang mana terdiri dari 29 orang siswa yang tuntas KKM dan 6 orang siswa yang tidak tuntas KKM, maka e-module ini dikategorikan sangat efektif. Adapun karakteristik e-module yang dibuat peneliti sebagai berikut: 1) Memiliki gambar dan video yang dapat menarik perhatian siswa, 2) Memiliki warna yang dapat menarik perhatian siswa, 3) Materi yang disajikan jelas, 4) E-module sebagai penunjang pembelajaran membantu perkembangan minat belajar siswa. Seorang siswa dikatakan telah mengerti dan memahami, apabila siswa tersebut mampu membandingkan, membedakan, dan memahami materi. Melihat hasil dari validitas, praktikalitas, dan efektifitas e-module pembelajaran matematika kelas V layak digunakan dengan kategori sangat valid, sangat praktis, dan sangat efektif. Hal ini sesuai dengan harapan atau tujuan dari penelitian yaitu e-module pembelajaran matematika kelas V yang valid, praktis, dan efektif.

\section{KESIMPULAN}

Berdasarkan pengembangan yang telah dilakukan terhadap e-module pembelajaran matematika pada materi bangun ruang, pengumpulan data dan penyajian data kelas V SD dapat disimpulkan pengembangan e-module pembelajaran matematika dengan menggunakan model 4-D dapat diuji cobakan di kelas V SD. Validitas e-module pembelajaran matematika yang dinilai validator yang berjumlah 3 orang, menunjukkan bahwa e-module pembelajaran matematika memperoleh persen $84 \%$ dengan kategori sangat valid, e-module pembelajaran matematika layak untuk digunakan dan sesuai dengan ketentuan SD. Praktikalitas yang dinilai dari angket respon guru terhadap e-module pembelajaran matematika yang berjumlah 1 orang guru di SD yaitu guru kelas V memperoleh persen 92\% dengan kategori sangat praktis sehingga media e-module pembelajaran matematika mampu memudahkan siswa dalam pembelajaran. Efektifitas yang dinilai dari hasil validasi tes akhir hasil belajar siswa memperoleh persen $83 \%$ dengan kaegori sangat efektif sehingga dapat dikatakan dengan digunakan e-module pembelajaran matematika mampu mencapaikan tujuan pembelajaran.

Penggunaan e-module pembelajaran dibuat dengan menggabungkan media (teks, gambar, audio, video, dan animasi) yang dapat menimbulkan terjadinya hubungan dua arah antara e-module dengan pengguna yang melibatkan penglihatan, pendengaran, sehingga siswa termotivasi untuk belajar mandiri, aktif, kreatif dalam belajar. 


\section{DAFTAR PUSTAKA}

Budiaji, W. (2013). Skala Pengukuran dan Jumlah Respon Skala Likert (The Measurement Scale and The Number of Responses in Likert Scale). Ilmu Pertanian Dan Perikanan, $2(2), 127-133$.

Kenedi, ary kiswanto. (2018). Kemampuan koneksi matematis siswa sekolah dasar dalam memecahakan masalah matematik. 5(2), 10.

Kurniawan, D., \& Dewi, S. V. (2017). Pengembangan Perangkat Pembelajaran Dengan Media Screencast- O-Matic Mata Kuliah Kalkulus 2 Menggunakan Model 4-D Thiagarajan. Jurnal Siliwangi, 3(1).

Matondang, Z. (2009). Validitas dan reliabilitas suatu instrumen penelitian. Jurnal Tabulara PPS UNIMED, 6(1), 87-97.

Prananda, G., Friska, S. Y., \& Susilawati, W. O. (2021). Pengaruh Media Konkret Terhadap Hasil Belajar Materi Operasi Hitung Campuran Bilangan Bulat Siswa Kelas IV Sekolah Dasar. JEMS: Jurnal Edukasi Matematika Dan Sains, 9(1), 1-10. https://doi.org/10.25273/jems.v9i1.8421

Ramadhani, R., \& Fitri, Y. (2020). Pengembangan E-Modul Matematika Berbasis Model Flipped-Blended Learning. Genta Mulia, 11(2), 150-163.

Ricu Sidiq, \& Najuah. (2020). Pengembangan E-Modul Interaktif Berbasis Android pada Mata Kuliah Strategi Belajar Mengajar. Jurnal Pendidikan Sejarah, 9(1), 1-14. https://doi.org/10.21009/jps.091.01

Suarsana, I. M., \& Mahayukti, G. A. (2013). Pengembangan E-Modul Berorientasi Pemecahan Masalah Untuk Meningkatkan Keterampilan Berpikir Kritis Mahasiswa. Jurnal Nasional Pendidikan Teknik Informatika (JANAPATI), 2(3), 193. https://doi.org/10.23887/janapati.v2i3.9800

Sugiyono. (2011). Metode Penelitian Kuantitatif, Kualitatif, dan R\&D. Bandung: ALFABETA, cv.

Sugiyono. (2016). Metode Penelitian Kuantitatif, Kualitatif, dan R\&D. Bandung: ALFABETA. 